\title{
Water Physicochemistry and Zooplankton Fauna of Aiba Reservoir Headwater Streams, Iwo, Nigeria
}

\author{
Emmanuel O. Akindele $e^{1,2}$ and Godwin O. Olutona ${ }^{3}$ \\ ${ }^{1}$ Department of Biological Sciences, Bowen University, PMB 284, Iwo, Osun State, Nigeria \\ ${ }^{2}$ Department of Biological Sciences, Federal University Ndufu-Alike Ikwo, PMB 1010, Abakaliki, Ebonyi State, Nigeria \\ ${ }^{3}$ Department of Chemistry and Industrial Chemistry, Bowen University, PMB 284, Iwo, Osun State, Nigeria
}

Correspondence should be addressed to Emmanuel O. Akindele; eoakindele@yahoo.com

Received 22 May 2014; Revised 17 October 2014; Accepted 22 October 2014; Published 19 November 2014

Academic Editor: Wen-Cheng Liu

Copyright (C) 2014 E. O. Akindele and G. O. Olutona. This is an open access article distributed under the Creative Commons Attribution License, which permits unrestricted use, distribution, and reproduction in any medium, provided the original work is properly cited.

\begin{abstract}
The physicochemical water condition and zooplankton fauna of the two main inflows of Aiba Reservoir were assessed over an annual hydrological cycle (May 2013-March 2014). The concentrations of total solids (TS) and total suspended solids (TSS) in the two streams were unusually higher in the dry season for typical inland waters of Nigeria and showed a decrease from the upper reaches towards the lower reaches (reservoir's inlet). Dissolved oxygen, $\mathrm{NO}_{3}{ }^{-}$, and $\mathrm{PO}_{4}{ }^{3-}$ recorded their highest concentrations at the reservoir's inlet. A total of 37 species of zooplankton were recorded in the study, comprising 5 species of Protozoa, 14 species of Rotifera, 10 species of Copepoda, 4 species of Ostracoda, and 4 species of Insecta. Aiba stream recorded higher number of zooplankton species and abundance than Onikan stream. While number of zooplankton species and abundance showed an increase from the upper reaches to the lower reaches of both streams, species diversity and equitability generally showed a decrease. Correlation and regression analysis suggests that the concentration of TS and TSS played a major role in determining the zooplankton community structure of the streams. $\mathrm{PO}_{4}{ }^{3-}$ concentrations as well as the community structures of zooplankton faunas of the two streams were indicative of a polluted freshwater system with unstable habitat structure.
\end{abstract}

\section{Introduction}

Throughout human history, water has played a dual role as a life-giving liquid and as a resource for waste disposal. Without careful management, these two uses can conflict, potentially dangerously. In the developed world, water pollution reached crisis proportions around the mid-twentieth century but is now increasingly controlled. In developing countries however, poor water quality remains a major health threat. Also, while economic growth in developed countries has helped to bring about improvements in water quality, many developing countries are finding it difficult to follow this trend [1]. Ensuring that water quality in aquatic environments remains within natural ranges is essential for sustaining viable, abundant, and diverse communities of organisms. Degradation of water quality erodes the availability of water for humans and ecosystem and decreases species diversity and abundance of resident communities. The changes in environmental quality can be associated with changes in water quality parameters such as sediment load, nutrient concentration, temperature, dissolved oxygen levels, and $\mathrm{pH}$ [2].

Freshwater zooplankton in the tropics comprises predominantly the rotifers, cladocerans, copepods, and occasionally the ostracods and insects [3]. Crustacean plankton has been described as preferred fish food items by several authors (e.g., [4-6]). They are preferred by fishes to their Rotifera counterparts for several reasons. First, they are relatively bigger, and planktivorous fishes which practice sizeselective predation often prefer them to the rotifers $[6,7]$. Also, unlike the rotifers which are not easily spotted by predatory fishes as a result of their transparent lorica [8], crustaceans are easily spotted. Furthermore, crustaceans are more important than rotifers in the transfer of energy from autotrophic phytoplankton to fishes based on their ecological niche in freshwater systems. Rotifers are mostly herbivorous which 
TABLE 1: Description of the study area.

\begin{tabular}{|c|c|c|c|}
\hline \multirow{2}{*}{ Lotic system } & \multicolumn{2}{|c|}{ Grid coordinates } & \multirow{2}{*}{ Site description } \\
\hline & Latitude & Longitude & \\
\hline $\begin{array}{l}\text { Aiba stream } \\
\text { (upper reaches/riffle) }\end{array}$ & $07^{\circ} 38^{\prime} .579^{\prime \prime} \mathrm{N}$ & $004^{\circ} 12^{\prime} .572^{\prime \prime} \mathrm{E}$ & $\begin{array}{l}\text { Adjacent to herdsmen's settlement; } 90 \% \text { vegetation cover; human } \\
\text { activities include farming and cattle rearing }\end{array}$ \\
\hline $\begin{array}{l}\text { Aiba stream } \\
\text { (lower reaches/reservoir's inlet) }\end{array}$ & $07^{\circ} 38^{\prime} .582^{\prime \prime} \mathrm{N}$ & $004^{\circ} 12^{\prime} .571^{\prime \prime} \mathrm{E}$ & $\begin{array}{l}\text { Closest to the reservoir; } 50 \% \text { vegetation cover; human activities } \\
\text { include farming, bathing, and washing }\end{array}$ \\
\hline $\begin{array}{l}\text { Onikan upstream } \\
\text { (upper reaches/riffle) }\end{array}$ & $07^{\circ} 38^{\prime} .583^{\prime \prime} \mathrm{N}$ & $004^{\circ} 12^{\prime} .570^{\prime \prime} \mathrm{E}$ & $\begin{array}{l}\text { Opposite the Muslim praying ground; } 10 \% \text { vegetation cover; } \\
\text { human activities include washing and encroachment. Site also } \\
\text { traverses a major road }\end{array}$ \\
\hline $\begin{array}{l}\text { Onikan stream } \\
\text { (lower reaches/reservoir's inlet) }\end{array}$ & $07^{\circ} 38^{\prime} .584^{\prime \prime} \mathrm{N}$ & $004^{\circ} 12^{\prime} .569^{\prime \prime} \mathrm{E}$ & $\begin{array}{l}\text { Closest to the reservoir; } 40 \% \text { vegetation cover; human activities } \\
\text { include farming, palm oil processing, and logging }\end{array}$ \\
\hline
\end{tabular}

could limit the amount of energy being harnessed from them by organisms at higher trophic levels, except there are intermediaries like crustaceans which feed on the rotifers. There is good evidence that rotifer species are differentially influenced by crustaceans via predation and competition [9]. Cyclopoid copepods have in particular been described as effective predators of rotifers [10], and so are some calanoid species which may include rotifers in their diets too [11, 12]. Aside their importance in fisheries, crustacean plankton (some cyclopoids) are also ecologically important by suppressing mosquito larvae. They are also known as intermediate hosts in the transmission of many parasites, especially worms. Some pathogenic human bacteria are carried and nurtured by Copepoda [13].

The vast majority of headwaters are rural streams with few urban influences. Their catchments are used primarily for farming. However, their rural context still leaves them vulnerable to broad spectrum of environmental stresses. These stresses may be exacerbated by the small size and low discharge of these streams, which limit the capacity to buffer either physical or chemical impacts [14]. The significance of headwater streams in freshwater systems cannot be overemphasized but is unfortunately often ignored in limnological studies. For instance, Aiba Reservoir has been copiously studied (e.g., $[6,15,16])$ but with little or no attention on its adjacent streams. Not until recently were studies carried out in the downstream section of the reservoir [17-19]. Previous zooplankton studies of the reservoir and its outflowing stream indicated a wide disparity in their compositions and community structures. While the reservoir was dominated by copepods [6], its receiving stream was dominated by rotifers [18]. Furthermore, while the previous physicochemical study of the reservoir indicated a healthy system [15], that of its outflowing stream indicated a stressed system [19]. Several studies have been carried out on the zooplankton fauna and water quality of Nigerian freshwaters, but such studies have always focused on reservoirs, lakes, and large rivers with no due attention on their headwater streams. There are very few studies which took cognizance of the significance of reservoirs' headwater streams and their zooplankton communities and which attempted to relate such findings to the downstream lake/reservoir, for example, Opa Reservoir [20] and Lake Tiga [21, 22]. Since there have been several limnological studies on Aiba Reservoir with no documented findings on its headwater streams, this study was motivated by the need to bridge the information gap on the streams' hydrology, water physicochemistry, and zooplankton fauna, since the health of a reservoir is intrinsic to its catchment area.

\section{Materials and Methods}

2.1. The Study Area. The study was carried out in the headwater streams (Aiba stream and Onikan stream) of Aiba Reservoir, Iwo, Osun State, Nigeria. Like most places in Southern Nigeria, the area is dominated by two major air masses (North East Trade Wind and South West Trade Wind) which shape the various seasons of the years. The North East Trade Wind which is dry and cold is predominant between November and February while the hot humid South West Trade Wind is predominant between April and October. The expected mean onset date of rainy season in the study area falls between March 13 and April 12 of a year, while the expected cessation date falls between October 19 and November 18. The annual regime of rainfall shows two peaks, one in July and the other in September [23]. One of the streams (Aiba stream) is characterized by Riparian forest with a heavy (70-90\%) vegetation cover. Anthropogenic activities in and around the streams include washing of clothes, rearing of cattle, farming, and foot crossing of water course (especially in the upstream of Aiba stream).

2.2. Sampling Regime and Sample Collection. Samples were collected over an annual circle between May 2013 and March 2014 based on projected hydrological conditions of the streams, in every other month with a mind to capture the various seasons in the study area/duration. These were May 2013 (early rainy season), July 2013 (first peak of rainy season), September 2013 (second peak of rainy season), November 2013 (early dry/harmattan season), January (2014 (mid-dry/ peak of harmattan season), and March 2014 (late dry season).

Two sampling stations were established on each of the streams, one at the upper reaches and the other at the lower reaches/inlet of the reservoir (Table 1). In situ water determinations included water temperature using a mercuryin-glass thermometer, water depth and Secchi disc depth (transparency), water channel width using a calibrated tape, flow velocity using a float displacement method, and water 
discharge (derived from the product of water depth, water channel width, and flow velocity). Others were $\mathrm{pH}$ using a calibrated $\mathrm{pH}$ meter (pHTestr2, Eutech Instruments, Malaysia) and electrical conductivity using a calibrated conductivity meter. Dissolved oxygen samples were also fixed in situ using Winkler's reagents. Pelagic water samples were collected at the stations just below the surface for both physicochemical and zooplankton analyses in the laboratory. In the case of physicochemical analyses, samples were collected in $2 \mathrm{~L}$ plastic containers, first washed with liquid detergent, and rinsed with distilled water. They were then soaked in $10 \%$ nitric acid for $48 \mathrm{~h}$. This was followed by vigorous rinsing three times with distilled water. The plastic bottles meant for sampling were further rinsed thrice on site with stream water to be sampled. The samples were transported to the laboratory and stored in refrigerators pending their analyses which were carried out within their holding time. Zooplankton samples were collected by towing a plankton net $(64 \mu \mathrm{m}$ mesh size) over a horizontal distance of $2 \mathrm{~m}$. The samples were collected in a $100 \mathrm{~mL}$ bottle and preserved in $5 \%$ formalin solution.

\subsection{Laboratory Analyses}

2.3.1. Physicochemical Analysis. All chemicals used were AnalaR grade (BDH, England). Sulphate was determined by turbidimetric method [24]; phosphate was determined by colorimetric technique (APHA 1998); nitrate was determined by ultraviolet screening method [25]; total alkalinity, total hardness, and dissolved oxygen were also determined by methods described by Ademoroti [24]. The concentrations of suspended and dissolved solids were determined using the gravimetric method [25].

2.3.2. Quality Assurance and Control. To assess the precision and accuracy of results, replicate analysis of blanks, standard, and samples was carried out. The standard deviations were determined to find the precision of the analysis.

2.3.3. Zooplankton Analysis. In the laboratory, the $100 \mathrm{~mL}$ concentrate samples were further decanted using a hand pipette and reduced to $5 \mathrm{~mL}$ for microscopic viewing and identification under a calibrated compound light microscope (Max II 1202.4000) fitted with an ocular micrometer. Identification was aided with the use of several guides (e.g., $[3,26])$ and observed morphometric features. The original volume of water filtered through the plankton net was estimated by using the formula $V=\wedge r^{2} d$, where $V=$ volume of water filtered; $r=$ the radius of the mouth of the net; $d=$ length of the water column traversed by the net.

The actual abundance of zooplankton in each sample was estimated from the count records of the final concentrate volume in relation to the original volume of water filtered by the plankton net.

2.3.4. Data Analyses. The data were subjected to various statistical analyses (e.g., descriptive analysis, Mann-Whitney $U$ test, and correlation analysis) and diversity analyses (e.g., species diversity and equitability) using the PAleontological STatistics (PAST) software.

\section{Results}

3.1. Physicochemical Water Parameters. Descriptive statistics and seasonal/temporal variations of physicochemical parameters of water in the two streams are presented in Tables 2 and 3. In terms of hydrological parameters, higher values of water depth, channel width, and water discharge were recorded in Aiba stream, while a higher value of flow velocity was recorded in Onikan stream. Temporally, higher values of hydrological variables were recorded in the rainy season than in the dry season, although none was significant $(P>0.05)$. With the exception of total suspended solids (TSS) in Onikan stream which recorded higher values in the rainy season $(P>$ 0.05 ), the concentrations of solids - total solids (TS in both streams), total dissolved solids (TDS in both streams), and TSS (in Aiba stream) - were higher in the dry season than in the rainy season. Of these solids, only TDS showed significant seasonal variation $(P<0.05)$. Higher value of $\mathrm{pH}$ and lower value of electrical conductivity were recorded in Aiba stream in comparison with the Onikan stream. In both streams, $\mathrm{pH}$ was lower $(P>0.05)$ and electrical conductivity was higher $(P>0.05)$ in the dry season than in the rainy season. Total alkalinity was significantly higher $(P<0.05)$ in the rainy season than in the dry season in the Onikan lotic system. Higher values of nutrient parameters $\left(\mathrm{NO}_{3}{ }^{-}\right.$and $\left.\mathrm{PO}_{4}{ }^{3-}\right)$ and lower concentration of dissolved oxygen (DO) were recorded in Aiba stream than in Onikan stream. Higher concentrations of $\mathrm{DO}, \mathrm{NO}_{3}{ }^{-}$, and $\mathrm{PO}_{4}{ }^{3-}$ were recorded in the dry season in both streams but with no significant difference $(P>0.05)$.

Spatially (Table 4), hydrological variables, save the flow velocity in both streams, showed an increase from the upper reaches of both systems downstream towards the reservoir inlet. Significant spatial variations $(P<0.05)$ in the environmental variables of Aiba stream included water depth, Secchi depth, TS, TSS, and DO, while those of Onikan stream were water depth, Secchi depth, and channel width. The concentrations of solids also showed a downward trend from the upper reaches of both streams towards the reservoir inlet, though not all were significant. $\mathrm{pH}$ and electrical conductivity both showed a nonsignificant decrease $(P>0.05)$ in the two streams towards the reservoir inlet. In both streams, $\mathrm{NO}_{3}{ }^{-}$, $\mathrm{PO}_{4}{ }^{3-}$, and $\mathrm{DO}$ generally showed an increase towards the reservoir inlet, although a significant variation $(P<0.05)$ was only recorded for DO in the case of Aiba stream.

The interrelationships among the physicochemical parameters in the two streams are shown in Figures 1 and 2. Three major clusters were observed among the parameters in Aiba stream at $P<0.05$. The first cluster was among water temperature, DO, flow velocity, and water discharge while the second was among water depth, Secchi depth, flow velocity, channel width, and water discharge. The third cluster in Aiba stream was among conductivity, TS, TDS and TSS, and $\mathrm{PO}_{4}{ }^{3-}$. Three major clusters were also observed in Onikan stream at $P<0.05$. Water temperature, $\mathrm{pH}$, and $\mathrm{DO}$ formed the first cluster while the second was among water depth, 
TABle 2: Descriptive statistics and seasonal variation of water physicochemical parameters in Aiba lotic system (May 2013-March 2014).

\begin{tabular}{|c|c|c|c|c|c|c|c|}
\hline \multirow[t]{2}{*}{ Parameter } & \multicolumn{3}{|c|}{ Descriptive statistics } & \multicolumn{2}{|c|}{ Seasonal variation } & \multicolumn{2}{|c|}{$\begin{array}{c}\text { Mann-Whitney } \\
U \text { test }\end{array}$} \\
\hline & Minimum & Maximum & Mean \pm S.D. & Rainy season & Dry season & $U$ & $P$ \\
\hline Water temperature $\left({ }^{\circ} \mathrm{C}\right)$ & 24.5 & 29.0 & $26.4 \pm 1.6$ & $26.0 \pm 1.3$ & $26.9 \pm 2.0$ & 12.5 & 0.4237 \\
\hline Water depth $(\mathrm{m})$ & 0.6 & 1.8 & $1.0 \pm 0.4$ & $1.0 \pm 0.4$ & $1.0 \pm 0.4$ & 17 & 0.9362 \\
\hline Secchi depth (m) & 0.10 & 0.90 & $0.41 \pm 0.22$ & $0.35 \pm 0.21$ & $0.47 \pm 0.24$ & 13.5 & 0.5222 \\
\hline Channel width (m) & 10.0 & 18.0 & $14.7 \pm 2.7$ & $14.7 \pm 3.2$ & $14.7 \pm 2.5$ & 17 & 0.9362 \\
\hline Flow velocity (m/s) & 0 & 0.05 & $0.016 \pm 0.017$ & $0.02 \pm 0.02$ & $0.011 \pm 0.008$ & 18 & 0.9362 \\
\hline Discharge $\left(\mathrm{m}^{3} / \mathrm{s}\right)$ & 0 & 1.440 & $0.334 \pm 0.491$ & $0.178 \pm 0.127$ & $0.165 \pm 0.164$ & 17 & 0.9362 \\
\hline TS (mg/L) & 86 & 773 & $191 \pm 188$ & $132 \pm 62$ & $251 \pm 257$ & 8 & 0.1282 \\
\hline TSS (mg/L) & 16 & 643 & $127 \pm 169$ & $96 \pm 58$ & $157 \pm 240$ & 16 & 0.8102 \\
\hline TDS (mg/L) & 30 & 130 & $64 \pm 31$ & $36 \pm 5$ & $86 \pm 25$ & $\mathbf{0}$ & 0.0051 \\
\hline $\mathrm{pH}$ & 6.65 & 8.30 & $7.24 \pm 0.55$ & $7.50 \pm 0.66$ & $6.97 \pm 0.26$ & 8 & 0.1285 \\
\hline Electrical conductivity $(\mu \mathrm{S} / \mathrm{cm})$ & 90.0 & 186.0 & $121.7 \pm 29.8$ & $116.7 \pm 19.7$ & $126.7 \pm 38.8$ & 17 & 0.9362 \\
\hline Total alkalinity $\left(\mathrm{mgCaCO}_{3} / \mathrm{L}\right)$ & 16.0 & 62.0 & $36.3 \pm 14.6$ & $39.4 \pm 15.1$ & $33.3 \pm 14.7$ & 14 & 0.5752 \\
\hline $\mathrm{PO}_{4}^{3-}(\mathrm{mg} / \mathrm{L})$ & 0 & 2.09 & $0.75 \pm 0.65$ & $0.45 \pm 0.35$ & $1.05 \pm 0.76$ & 10 & 0.2298 \\
\hline $\mathrm{NO}_{3}^{-}(\mathrm{mg} / \mathrm{L})$ & 0 & 1.25 & $0.57 \pm 0.42$ & $0.43 \pm 0.43$ & $0.71 \pm 0.37$ & 11.5 & 0.3367 \\
\hline Dissolved oxygen (mg/L) & 0.7 & 7.5 & $4.3 \pm 2.2$ & $3.7 \pm 1.6$ & $4.9 \pm 2.7$ & 14 & 0.5752 \\
\hline
\end{tabular}

$n=12$, critical value of $U=5$ at $P<0.05$.

TABLE 3: Descriptive statistics and seasonal variation of water physicochemical parameters in Onikan lotic system (May 2013-March 2014).

\begin{tabular}{|c|c|c|c|c|c|c|c|}
\hline \multirow[t]{2}{*}{ Parameter } & \multicolumn{3}{|c|}{ Descriptive statistics } & \multicolumn{2}{|c|}{ Seasonal variation } & \multicolumn{2}{|c|}{$\begin{array}{c}\text { Mann-Whitney } \\
U \text { test }\end{array}$} \\
\hline & Minimum & Maximum & Mean \pm S.D. & Rainy season & Dry season & $U$ value & $P$ value \\
\hline Water temperature $\left({ }^{\circ} \mathrm{C}\right)$ & 24.8 & 29.0 & $26.4 \pm 1.5$ & $25.3 \pm 0.6$ & $27.6 \pm 1.3$ & 6.5 & 0.0784 \\
\hline Water depth (m) & 0.2 & 1.2 & $0.7 \pm 0.4$ & $0.8 \pm 0.5$ & $0.6 \pm 0.4$ & 15 & 0.6892 \\
\hline Secchi depth (m) & 0.20 & 0.70 & $0.40 \pm 0.21$ & $0.36 \pm 0.21$ & $0.46 \pm 0.22$ & 16.5 & 0.8729 \\
\hline Channel width (m) & 1.0 & 5.0 & $3.1 \pm 1.4$ & $3.6 \pm 1.7$ & $2.7 \pm 1.0$ & 15.5 & 0.7488 \\
\hline Flow velocity (m/s) & 0 & 0.33 & $0.092 \pm 0.129$ & $0.113 \pm 0.141$ & $0.067 \pm 0.124$ & 8 & 0.1282 \\
\hline Discharge $\left(\mathrm{m}^{3} / \mathrm{s}\right)$ & 0 & 0.300 & $0.102 \pm 0.126$ & $0.113 \pm 0.131$ & $0.089 \pm 0.133$ & 9.5 & 0.2002 \\
\hline TS (mg/L) & 62 & 198 & $146 \pm 47$ & $146 \pm 36$ & $147 \pm 63$ & 17 & 0.9362 \\
\hline TSS (mg/L) & 12 & 130 & $78 \pm 42$ & $99 \pm 23$ & $53 \pm 48$ & 5.5 & 0.0547 \\
\hline TDS (mg/L) & 34 & 144 & $68 \pm 37$ & $47 \pm 18$ & $94 \pm 39$ & 9 & 0.1735 \\
\hline $\mathrm{pH}$ & 6.70 & 8.00 & $7.16 \pm 0.46$ & $7.17 \pm 0.48$ & $7.14 \pm 0.49$ & 14.5 & 0.6312 \\
\hline Electrical conductivity $(\mu \mathrm{S} / \mathrm{cm})$ & 85.0 & 300.0 & $175.2 \pm 72.6$ & $127.4 \pm 67.4$ & $190.0 \pm 79.5$ & 10 & 0.2298 \\
\hline Total alkalinity $\left(\mathrm{mgCaCO}_{3} / \mathrm{L}\right)$ & 14 & 82 & $39.0 \pm 18.6$ & $48.7 \pm 17.8$ & $27.3 \pm 12.4$ & 4.5 & 0.0374 \\
\hline $\mathrm{PO}_{4}^{3-}(\mathrm{mg} / \mathrm{L})$ & 0 & 0.98 & $0.56 \pm 0.39$ & $0.50 \pm 0.41$ & $0.64 \pm 0.39$ & 18 & 0.9362 \\
\hline $\mathrm{NO}_{3}^{-}(\mathrm{mg} / \mathrm{L})$ & 0 & 1.4 & $0.51 \pm 0.42$ & $0.42 \pm 0.52$ & $0.63 \pm 0.27$ & 13 & 0.4712 \\
\hline Dissolved oxygen $(\mathrm{mg} / \mathrm{L})$ & 4.5 & 7.8 & $5.9 \pm 1.2$ & $5.1 \pm 0.6$ & $6.8 \pm 1.1$ & 8.5 & 0.1495 \\
\hline
\end{tabular}

$n=12$, critical value of $U=5$ at $P<0.05$.

Secchi depth, channel width, $\mathrm{PO}_{4}{ }^{3-}$, and $\mathrm{NO}_{3}{ }^{-}$. Total alkalinity, flow velocity, water discharge, TS, and TSS formed the last major cluster in Onikan stream.

3.2. Zooplankton Fauna, Community Structure, and Their Relationship with Water Physicochemical Parameters. A total of 37 species of zooplankton comprise 5 species of Protozoa, 14 species of Rotifera, 10 species of Copepoda, 4 species of Ostracoda, and 4 species of Insecta (Table 5). The comparative compositions and community structures of zooplankton in the two streams are shown in Table 6. Aiba stream recorded more species and higher abundance than Onikan stream. Although number of species and abundance showed an increase towards the reservoir in both streams, significant spatial variation $(P<0.05)$ in number of species was only recorded in Onikan stream while significant spatial variation $(P<0.05)$ in abundance was recorded in both streams. Only four taxa (Mesocyclops ogunnus, Microcyclops varicans, nauplius larva, and chironomid sp.) were recorded in all the 
TABLe 4: Spatial variation of water physicochemical parameters in Aiba and Onikan lotic systems (May 2013-March 2014).

\begin{tabular}{|c|c|c|c|c|}
\hline \multirow{2}{*}{ Parameter } & \multirow{2}{*}{ Upper reaches } & \multirow{2}{*}{ Lower reaches } & \multicolumn{2}{|c|}{ Mann-Whitney $U$ test } \\
\hline & & & $U$ value & $P$ value \\
\hline \multicolumn{5}{|c|}{ Aiba stream } \\
\hline Water temperature $\left({ }^{\circ} \mathrm{C}\right)$ & $25.6 \pm 1.3$ & $27.3 \pm 1.6$ & 7 & 0.0927 \\
\hline Water depth $(\mathrm{m})$ & $0.8 \pm 0.1$ & $1.3 \pm 0.4$ & 2.5 & 0.0163 \\
\hline Secchi depth (m) & $0.26 \pm 0.14$ & $0.56 \pm 0.18$ & 3 & 0.0202 \\
\hline Channel width (m) & $14.3 \pm 2.3$ & $15.0 \pm 3.3$ & 15 & 0.6889 \\
\hline Flow velocity $(\mathrm{m} / \mathrm{s})$ & $0.022 \pm 0.022$ & $0.009 \pm 0.009$ & 11 & 0.298 \\
\hline Discharge $\left(\mathrm{m}^{3} / \mathrm{s}\right)$ & $0.252 \pm 0.116$ & $0.473 \pm 0.635$ & 10 & 0.2298 \\
\hline $\mathrm{TS}(\mathrm{mg} / \mathrm{L})$ & $269 \pm 251$ & $114 \pm 26$ & 3 & 0.0202 \\
\hline TSS (mg/L) & $200 \pm 223$ & $53 \pm 19$ & 2 & 0.0131 \\
\hline TDS (mg/L) & $69 \pm 36$ & $61 \pm 28$ & 16.5 & 0.8728 \\
\hline $\mathrm{pH}$ & $7.27 \pm 0.76$ & $7.20 \pm 0.29$ & 12 & 0.3785 \\
\hline Electrical conductivity $(\mu \mathrm{S} / \mathrm{cm})$ & $126.0 \pm 32.4$ & $117.3 \pm 29.3$ & 13.5 & 0.5218 \\
\hline Total alkalinity $\left(\mathrm{mgCaCO}_{3} / \mathrm{L}\right)$ & $36.1 \pm 16.0$ & $36.6 \pm 14.5$ & 17 & 0.9362 \\
\hline $\mathrm{PO}_{4}{ }^{3-}(\mathrm{mg} / \mathrm{L})$ & $0.65 \pm 0.77$ & $0.86 \pm 0.55$ & 10.5 & 0.2623 \\
\hline $\mathrm{NO}_{3}^{-}(\mathrm{mg} / \mathrm{L})$ & $0.57 \pm 0.41$ & $0.57 \pm 0.45$ & 16.5 & 0.8728 \\
\hline Dissolved oxygen (mg/L) & $2.6 \pm 1.4$ & $5.9 \pm 1.6$ & 2 & 0.0131 \\
\hline \multicolumn{5}{|c|}{ Onikan stream } \\
\hline Water temperature $\left({ }^{\circ} \mathrm{C}\right)$ & $25.9 \pm 1.5$ & $26.7 \pm 1.5$ & 10.5 & 0.2623 \\
\hline Water depth $(\mathrm{m})$ & $0.32 \pm 0.09$ & $0.98 \pm 0.32$ & 2.5 & 0.0163 \\
\hline Secchi depth (m) & $0.24 \pm 0.07$ & $0.54 \pm 0.18$ & 3.5 & 0.0250 \\
\hline Channel width (m) & $1.9 \pm 0.7$ & $4.1 \pm 0.9$ & 1 & 0.0082 \\
\hline Flow velocity $(\mathrm{m} / \mathrm{s})$ & $0.187 \pm 0.144$ & $0.014 \pm 0.019$ & 10 & 0.2298 \\
\hline Discharge $\left(\mathrm{m}^{3} / \mathrm{s}\right)$ & $0.146 \pm 0.136$ & $0.065 \pm 0.117$ & 15.5 & 0.7488 \\
\hline $\mathrm{TS}(\mathrm{mg} / \mathrm{L})$ & $184 \pm 20$ & $115 \pm 40$ & 8 & 0.1282 \\
\hline TSS (mg/L) & $106 \pm 31$ & $55 \pm 37$ & 11 & 0.298 \\
\hline TDS (mg/L) & $78 \pm 39$ & $60 \pm 36$ & 15 & 0.6889 \\
\hline $\mathrm{pH}$ & $7.38 \pm 0.63$ & $6.97 \pm 0.13$ & 17.5 & 1 \\
\hline Electrical conductivity $(\mu \mathrm{S} / \mathrm{cm})$ & $194.0 \pm 62.3$ & $159.5 \pm 82.3$ & 15.5 & 0.7488 \\
\hline Total alkalinity $\left(\mathrm{mgCaCO}_{3} / \mathrm{L}\right)$ & $45.5 \pm 23.5$ & $33.6 \pm 13.2$ & 17 & 0.9362 \\
\hline $\mathrm{PO}_{4}{ }^{3-}(\mathrm{mg} / \mathrm{L})$ & $0.43 \pm 0.39$ & $0.68 \pm 0.38$ & 10 & 0.2298 \\
\hline $\mathrm{NO}_{3}^{-}(\mathrm{mg} / \mathrm{L})$ & $0.36 \pm 0.28$ & $0.64 \pm 0.49$ & 9 & 0.1735 \\
\hline Dissolved oxygen $(\mathrm{mg} / \mathrm{L})$ & $5.8 \pm 1.4$ & $6.0 \pm 1.1$ & 13 & 0.4712 \\
\hline
\end{tabular}

$n=12$, critical value of $U=5$ at $P<0.05$.

stations in this study. Species with very rare occurrences were categorised as those that occurred in only one station each and had less than $50 \mathrm{ind} \cdot \mathrm{m}^{-3}$ abundance, and there were 15 species in this category. A total of $18,988 \mathrm{ind} \cdot \mathrm{m}^{-3}$ zooplankton abundance was recorded in this study, comprising $2.54 \%$ Protozoa, 3.71\% Rotifera, $85.86 \%$ Copepoda, 3.59\% Ostracoda, and $4.29 \%$ Insecta. The most abundant individual taxon was nauplius larva which accounted for $63.61 \%$ of the total abundance. Microcyclops varicans and Mesocyclops ogunnus also accounted for relatively high abundance with $5.45 \%$ and $5.11 \%$, respectively.

All the diversity indices employed save Margalef index recorded higher values in Onikan stream than in Aiba stream. Equitability of species also followed the same trend as the diversity indices by recording a higher value in Onikan stream. With the exception of Margalef index in Onikan stream, all other indices showed a decrease from the upper reaches towards the reservoir. Table 7 shows that number of species and Shannon-Weiner species diversity were higher in the rainy season than in the dry season $(P>0.05$ and $P<$ 0.05 , resp.). Generally, higher values of zooplankton abundance were recorded in the dry season than in the rainy season, with the exception of Onikan upstream where the reverse was the case.

Relationships between zooplankton fauna and water physicochemical parameters are presented in Table 8. Number of species showed a significant positive correlation $(P<$ $0.05)$ with Secchi depth and dissolved oxygen (DO) and a significant negative correlation with total solids $(P<0.01)$ and total suspended solids $(P<0.05)$. Abundance showed 


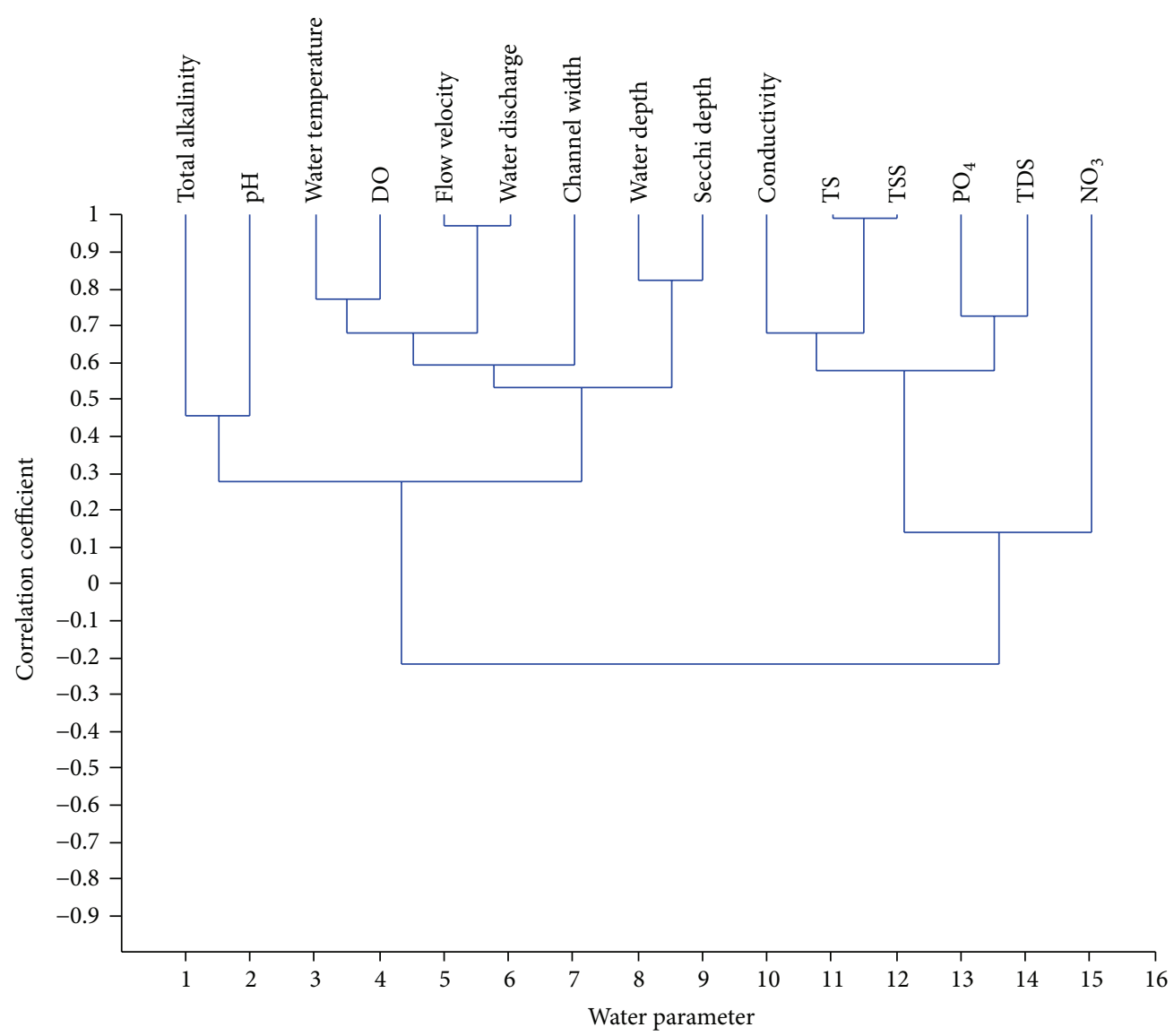

Figure 1: Multivariate (cluster) analysis of physicochemical parameters of water in Aiba lotic system (May 2013-March 2014) $(n=12$, $r=0.5324$ at $P<0.05)$.

a significant positive correlation with water temperature $(P<0.01)$ and DO $(P<0.001)$, while TS and TSS both showed a significant negative correlation with abundance. $\mathrm{pH}$ showed a significant positive correlation $(P<0.01)$ with Shannon-Weiner species diversity, while a significant negative correlation $(P<0.05)$ was recorded between total dissolved solids and Shannon-Weiner species diversity.

\section{Discussion}

Aiba stream seemed to make much more hydrological contribution than Onikan stream based on variables such as water depth, channel width, and water discharge. It could therefore be regarded as the main catchment of the reservoir, hence the name Aiba Reservoir. As a stream winds its way from its source to its mouth, the volume (discharge) of water passing down increases and the speed at which the water moves (flow velocity or current) decreases [27], as indicated by spatial variation of discharge in Aiba stream and that of flow velocity in Onikan stream. Since the volume or discharge capacity of a basin is dependent on water depth, water channel width, and the flow velocity of water [28], natural and human factors could go a long way in controlling these variables. Aiba stream, for instance, is relatively undisturbed as it meanders down the reservoir through a Riparian forest, while human interference and encroachment (as a result of expanding population) in and along the basin of Onikan stream has drastically reduced its discharge capacity. Onikan stream currently passes through the heart of the town and is greatly threatened by humans through competition for space. The negative impact of reduced discharge of a stream/river on a downstream reservoir cannot be overemphasized. Discharge influences the susceptibility of a stream to pollution. Large, swiftly flowing rivers or streams can receive pollution discharges and, through dilution, be little affected. In contrast, small, slow-flowing streams have a reduced capacity to attenuate and degrade wastes [2].

Stream velocity affects the amount of silt and sediment carried by the stream [2], and this could most likely justify the spatial trend in the concentrations of solids in the two streams. Sediment in slow-moving streams will settle to the stream bottom, whereas sediment in fast-moving waters will remain suspended in the water column, eventually settling in lakes and reservoirs [2]. The seasonal trend in the concentrations of solids (TS, TSS, and TDS) in both streams was at variance with the usual pattern for most inland waters in Nigeria (e.g., $[29,30])$. Except in a rare case of resuspension of autochthonous sediments in dry season due to human disturbances as the case was in this study, Nigerian streams and rivers usually record the highest concentrations of TS and TSS 


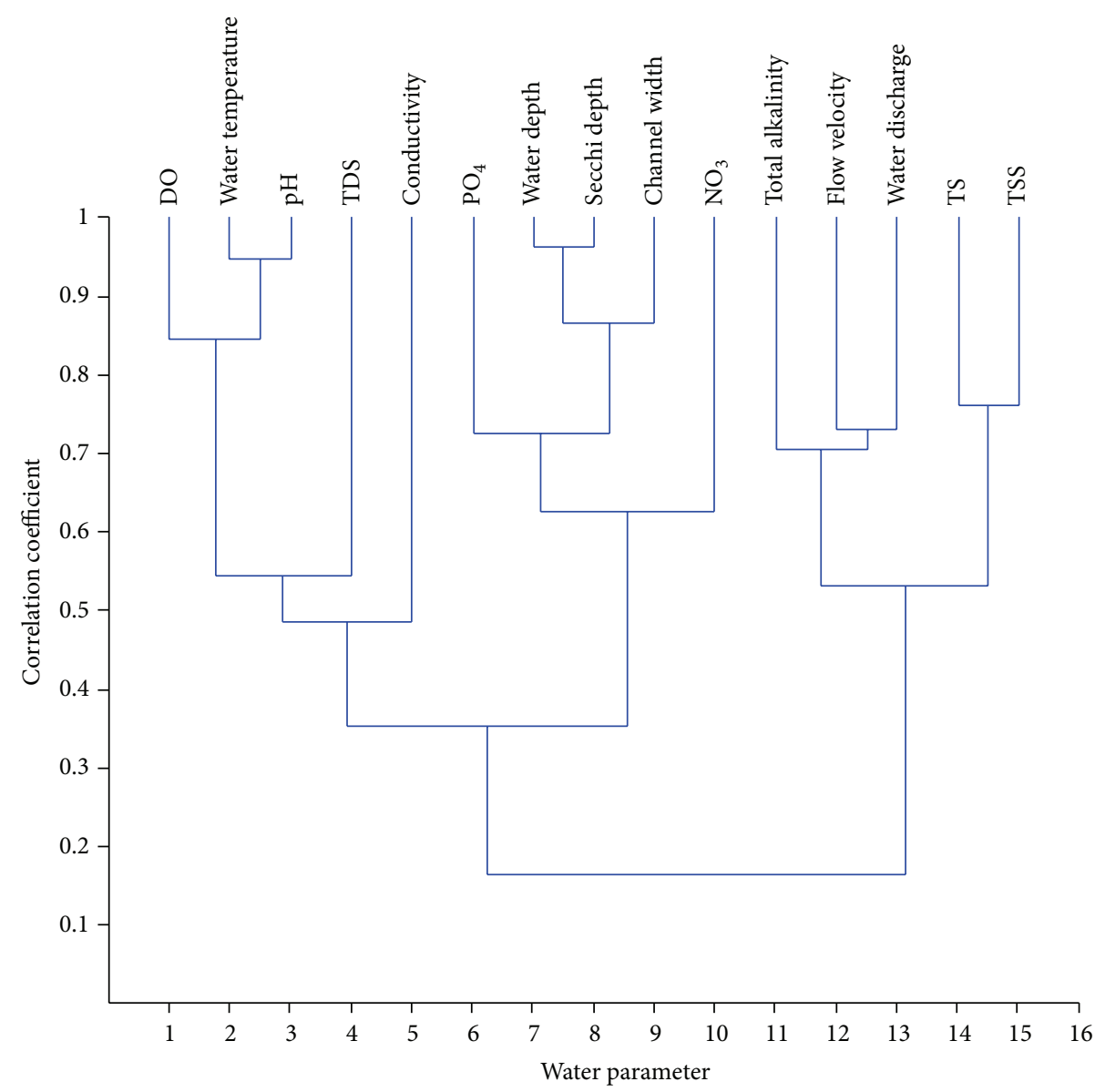

FIGURE 2: Multivariate (cluster) analysis of physicochemical parameters of water in Onikan lotic system (May 2013-March 2014) $(n=12$, $r=0.5324$ at $P<0.05)$.

in the rainy season as a result of allochthonous runoff from the surrounding terrestrial environments. The relatively high concentrations of TS and TSS recorded in the streams' riffles may be explained in the light of Voshell [31] who divided lotic habitats into two zones, that is, erosional or riffle zone and depositional or pool zone. The riffle is the zone where streams at normal flow (not just during floods) have sufficient power to pick up fine sediments, keep them in suspension, and transport them downstream. The pool is the area where the stream does not have sufficient power at normal flow to keep fine sediments in suspension, so the small particles in transport settle out on the bottom. $\mathrm{PO}_{4}{ }^{3-}$ concentration in the two streams was far above the maximum limit $(0.1 \mathrm{mg} / \mathrm{L})$ for aquatic life $[32,33]$, thus indicating a polluted system.

The interrelationships among the physicochemical parameters can be summarized into two groups. The first was among electrical conductivity, nutrient parameters $\left(\mathrm{NO}_{3}{ }^{-}\right.$ and $\mathrm{PO}_{4}{ }^{3-}$ ), and solids (TS, TSS, and TDS), while the second was among hydrological variables, solids, and nutrient parameters. These relationships go a long way to further establish the direct relationship of conductivity and TDS [25] and the importance of sediments (autochthonous or allochthonous) in the eutrophication of inland waters [34-36].
This study recorded more species of zooplankton than the previous zooplankton studies of the reservoir (17 taxa) and its outflowing stream (36 taxa). Furthermore, this study was uniquely different as Copepoda quantitatively dominated the zooplankton fauna of the headwater streams and there was no record of cladoceran zooplankton, in contrast with Rotifera dominance and cladoceran presence in comparable studies. Although Rotifera dominated the fauna qualitatively, their quantitative contribution was much lower than that of Copepoda, a greater percentage of which was recorded between November and March when the flow velocity was greatly reduced. The highest abundance of Copepoda was recorded between January and March when the streams were reduced to base flow (data not shown). It is expected that, during this period, zooplankton with longer generation times (e.g., Copepoda, Cladocera) will have sufficient time to grow in populations owing to the little or no flow velocity of their environments. The relatively low abundance of Rotifera in comparison with Copepoda may not also be unconnected with the predatory nature of the latter on the former [10-12]. Very striking in this study was the absence of Cladocera fauna, a taxon which rarely occurred in the reservoir and its outflowing stream, based on previous zooplankton studies. 
TABLE 5: Occurrence and abundance of zooplankton in Aiba Reservoir headwater streams (May 2013-March 2014).

\begin{tabular}{|c|c|c|c|c|c|}
\hline \multirow[b]{2}{*}{ Taxon } & \multicolumn{2}{|c|}{ Aiba stream } & \multicolumn{2}{|c|}{ Onikan stream } & \multirow[b]{2}{*}{$\begin{array}{l}\text { Total abundance } \\
\quad\left(\text { ind } \cdot \mathrm{m}^{-3} \text { ) }\right.\end{array}$} \\
\hline & $\begin{array}{c}\text { Upper reaches' } \\
\text { abundance } \\
\left(\text { ind } \cdot \mathrm{m}^{-3}\right)\end{array}$ & $\begin{array}{c}\text { Lower reaches' } \\
\text { abundance } \\
\left(\text { ind } \cdot \mathrm{m}^{-3}\right)\end{array}$ & $\begin{array}{l}\text { Upper reaches' } \\
\text { abundance } \\
\left(\text { ind } \cdot \mathrm{m}^{-3}\right)\end{array}$ & $\begin{array}{l}\text { Lower reaches' } \\
\text { abundance } \\
\left(\text { ind } \cdot \mathrm{m}^{-3}\right)\end{array}$ & \\
\hline \multicolumn{6}{|l|}{ Protozoa } \\
\hline Actinophrys sp. & 22 & - & - & - & 22 \\
\hline Amoeba radiata & 22 & - & - & 22 & 44 \\
\hline Arcella sp. & - & 286 & - & 22 & 308 \\
\hline Centropyxis sp. & - & - & - & 22 & 22 \\
\hline Loxodes magnus & - & - & - & 88 & 88 \\
\hline \multicolumn{6}{|l|}{ Rotifera } \\
\hline Anuraeopsis fissa & - & - & - & 44 & 44 \\
\hline Anuraeopsis racenensis & 44 & - & - & 22 & 66 \\
\hline Ascomorpha ovalis & 22 & - & - & - & 22 \\
\hline Asplanchna brightwelli & - & 22 & - & - & 22 \\
\hline Asplanchna priodonta & - & 198 & 22 & 44 & 264 \\
\hline Brachionus angularis & - & 22 & - & - & 22 \\
\hline Brachionus quadridentatus & - & 22 & - & 22 & 44 \\
\hline Euchlanis triquetra & 22 & - & - & - & 22 \\
\hline Keratella lenzi & - & - & - & 22 & 22 \\
\hline Lepadella patella biloba & 22 & - & - & - & 22 \\
\hline Lepadella patella similis & - & 44 & - & 22 & 66 \\
\hline Mytilina ventralis & - & - & - & 44 & 44 \\
\hline Testudinella patina & - & - & - & 22 & 22 \\
\hline Trichocerca sp. & - & - & - & 22 & 22 \\
\hline \multicolumn{6}{|l|}{ Copepoda } \\
\hline Bryocamptus minutus & 22 & - & - & - & 22 \\
\hline Cleptocampus sp. & 66 & 88 & - & - & 154 \\
\hline Eucyclops macrurus & 44 & 506 & - & 132 & 682 \\
\hline Halicyclops korodiensis & - & - & - & 88 & 88 \\
\hline Halicyclops troglodytes & - & - & - & 88 & 88 \\
\hline Mesocyclops ogunnus & 154 & 244 & 44 & 528 & 970 \\
\hline Microcyclops varicans & 44 & 528 & 22 & 440 & 1034 \\
\hline Nauplius larva & 506 & 7216 & 44 & 4312 & 12078 \\
\hline Thermocyclops crassus & - & 308 & - & 176 & 484 \\
\hline Thermocyclops neglectus & 22 & 396 & - & 286 & 704 \\
\hline \multicolumn{6}{|l|}{ Ostracoda } \\
\hline Chrissia humilis & - & 66 & - & - & 66 \\
\hline Hemicypris ovata & - & 22 & 22 & - & 44 \\
\hline Heterocypris makua & - & 308 & - & 110 & 418 \\
\hline Stenocypris derupta & 44 & 110 & - & - & 154 \\
\hline \multicolumn{6}{|l|}{ Insecta } \\
\hline Chaoborus sp. & 110 & - & - & 44 & 154 \\
\hline Ceratopogonid larva & - & 22 & - & - & 22 \\
\hline Chironomid sp. & 220 & 198 & 44 & 154 & 616 \\
\hline Coenagrion pulchellum & 22 & - & - & - & 22 \\
\hline Number of species & 17 & 19 & 6 & 24 & 37 \\
\hline Total abundance $\left(\right.$ ind $\cdot \mathrm{m}^{-3}$ ) & 1408 & 10606 & 198 & 6776 & 18988 \\
\hline
\end{tabular}


TABLE 6: Diversity indices of zooplankton fauna in Aiba Reservoir headwater streams (May 2013-March 2014).

\begin{tabular}{|c|c|c|c|c|c|}
\hline \multirow{2}{*}{ Diversity index } & \multirow{2}{*}{ Overall } & \multirow{2}{*}{ Upper reaches } & \multirow{2}{*}{ Lower reaches } & \multicolumn{2}{|c|}{ Mann-Whitney $U$ test } \\
\hline & & & & $U$ value & $P$ value \\
\hline \multicolumn{6}{|c|}{ Aiba stream } \\
\hline Number of species & 28 & 17 & 19 & 9 & 0.1735 \\
\hline Total abundance & 12014 & 1408 & 10606 & 3 & 0.0202 \\
\hline Shannon, $H^{\prime}$ & 1.624 & 2.196 & 1.423 & 14 & 0.5752 \\
\hline Simpson, $1-D$ & 0.5763 & 0.8203 & 0.5271 & 14 & 0.5752 \\
\hline Margalef & 2.874 & 2.207 & 1.942 & 12 & 0.3785 \\
\hline Menhinick & 0.2555 & 0.4531 & 0.1845 & 18 & 0.9362 \\
\hline Equitability, $J$ & 0.4874 & 0.7749 & 0.4834 & 14 & 0.5752 \\
\hline \multicolumn{6}{|c|}{ Onikan stream } \\
\hline Number of species & 25 & 6 & 24 & 2 & 0.0131 \\
\hline Total abundance & 6974 & 198 & 6776 & 1 & 0.0082 \\
\hline Shannon, $H^{\prime}$ & 1.632 & 1.735 & 1.59 & 4 & 0.0306 \\
\hline Simpson, $1-D$ & 0.5942 & 0.8148 & 0.5804 & 4 & 0.0306 \\
\hline Margalef & 2.712 & 0.9455 & 2.607 & 3 & 0.0202 \\
\hline Menhinick & 0.2994 & 0.4264 & 0.2916 & 12 & 0.3785 \\
\hline Equitability, $J$ & 0.5069 & 0.9684 & 0.5002 & 6 & 0.0656 \\
\hline
\end{tabular}

$n=12$, critical value of $U=5$ at $P<0.0$.

TABLE 7: Seasonal variation in the community structure of zooplankton in Aiba Reservoir headwater streams (May 2013-March 2014).

\begin{tabular}{|c|c|c|c|c|c|c|c|c|c|c|c|c|}
\hline \multirow{3}{*}{ Lotic system } & \multicolumn{4}{|c|}{ Number of species } & \multicolumn{4}{|c|}{ Abundance } & \multicolumn{4}{|c|}{ Shannon-Weiner diversity } \\
\hline & \multicolumn{2}{|c|}{ Season } & \multicolumn{2}{|c|}{$\begin{array}{c}\text { Mann-Whitney } \\
U \text { test }\end{array}$} & \multicolumn{2}{|c|}{ Season } & \multicolumn{2}{|c|}{$\begin{array}{c}\text { Mann-Whitney } \\
U \text { test }\end{array}$} & \multicolumn{2}{|c|}{ Season } & \multicolumn{2}{|c|}{$\begin{array}{c}\text { Mann-Whitney } \\
U \text { test }\end{array}$} \\
\hline & RS & DS & $U$ & $P$ & RS & DS & $U$ & $P$ & RS & DS & $U$ & $P$ \\
\hline \multicolumn{13}{|l|}{ Aiba stream } \\
\hline Upper reaches & 13 & 5 & & & 550 & 858 & & & 2.32 & 1.104 & & \\
\hline Lower reaches & 13 & 12 & & & 2288 & 8318 & & & 2.13 & 0.7511 & & \\
\hline Overall & 20 & 14 & & & 2838 & 9176 & & & 2.42 & 0.8509 & & \\
\hline Onikan stream & & & 53 & 0.2855 & & & 65 & 0.7075 & & & 30.5 & 0.0179 \\
\hline Upper reaches & 5 & 1 & & & 176 & 22 & & & 1.56 & 0 & & \\
\hline Lower reaches & 16 & 12 & & & 2266 & 4510 & & & 2.289 & 0.6293 & & \\
\hline Overall & 17 & 13 & & & 2442 & 4532 & & & 2.324 & 0.6569 & & \\
\hline
\end{tabular}

RS: rainy season, DS: dry season; $n=12$; critical value of $U=37$ at $P<0.05$.

Only one taxon of Cladocera (Daphnia sp.) was reported in the previous zooplankton study of the reservoir [6], while six taxa (Allonia affinis, Camptocercus rectirostris, Bosmina longirostris, Macrothrix laticornis, Moina micrura, and Moinodaphnia macleayi) were recorded in its outflowing stream [18]. Zooplanktivorous fishes have been reported to show preference for cladocerans above other groups [7]. The rare occurrence of cladocerans in these headwater streams could therefore affect the food preference and feeding of zooplanktivorous fishes in the reservoir. In terms of species composition and abundance, Aiba stream again recorded higher values than Onikan stream, underscoring its relevance to the hydrology and water quality of the reservoir. The various diversity indices recorded in this study were a clear indication of polluted and unstable habitats, that is, Margalef indices ranging from 1.0 to 3.0 and Shannon-Weiner indices $<3.0$ $[37,38]$.
There was a direct relationship between $\mathrm{pH}$ and species diversity, most likely because the recorded $\mathrm{pH}$ values fell within the WHO recommendation (6.0-8.5) for aquatic life [28]. This underscores the fact that neither an acidic medium nor an extremely alkaline medium is favourable for aquatic life. Secchi depth (water transparency), DO, and water temperature favoured the composition and abundance of zooplankton in this study as indicated by their significant direct relationships, while the concentrations of TS and TSS could be considered limiting owing to the inverse relationships they showed with species composition and abundance. These relationships could also explain the spatial trend in species composition and abundance of zooplankton in the two streams. Generally, higher number of species and abundance were recorded at the reservoir's inlet in both streams, and these incidentally recorded lower concentrations of solids as well as higher values of water transparency and DO. The spatial 
TABLE 8: Relationships of water physicochemical parameters with zooplankton fauna in Aiba Reservoir headwater streams (May 2013-March 2014).

\begin{tabular}{|c|c|c|c|c|c|c|}
\hline \multirow[b]{2}{*}{ Parameter } & \multicolumn{2}{|c|}{$\begin{array}{l}\text { Pearson's correlation with } \\
\text { number of species }\end{array}$} & \multicolumn{2}{|c|}{$\begin{array}{l}\text { Pearson's correlation with } \\
\text { abundance }\end{array}$} & \multicolumn{2}{|c|}{$\begin{array}{l}\text { Pearson's correlation with } \\
\text { species diversity, } H^{\prime}\end{array}$} \\
\hline & $\begin{array}{l}\text { Aiba stream } \\
\quad(n=12)\end{array}$ & $\begin{array}{l}\text { Onikan stream } \\
\quad(n=12)\end{array}$ & $\begin{array}{l}\text { Aiba stream } \\
\quad(n=12)\end{array}$ & $\begin{array}{l}\text { Onikan stream } \\
\quad(n=12)\end{array}$ & $\begin{array}{l}\text { Aiba stream } \\
\quad(n=12)\end{array}$ & $\begin{array}{l}\text { Onikan stream } \\
\quad(n=12)\end{array}$ \\
\hline Water temperature $\left({ }^{\circ} \mathrm{C}\right)$ & 0.3247 & 0.0767 & $0.7052^{* *}$ & 0.4206 & 0.0927 & -0.3132 \\
\hline Water depth (m) & 0.2341 & 0.4530 & 0.4322 & 0.4717 & 0.2251 & 0.3366 \\
\hline Secchi depth (m) & $0.5967^{*}$ & 0.3613 & 0.4162 & 0.4703 & 0.4331 & 0.1469 \\
\hline Channel width (m) & 0.1029 & 0.4597 & 0.0530 & 0.4528 & 0.3319 & 0.2586 \\
\hline Flow velocity $(\mathrm{m} / \mathrm{s})$ & -0.0627 & -0.4299 & 0.4801 & -0.4065 & 0.0795 & -0.2110 \\
\hline Discharge $\left(\mathrm{m}^{3} / \mathrm{s}\right)$ & -0.0876 & -0.3910 & 0.5273 & -0.4080 & -0.0170 & -0.0283 \\
\hline $\mathrm{TS}(\mathrm{mg} / \mathrm{L})$ & $-0.5998^{*}$ & $-0.7316^{* *}$ & -0.3196 & $-0.6635^{* *}$ & -0.5276 & -0.3429 \\
\hline TSS (mg/L) & $-0.6013^{*}$ & $-0.5421^{*}$ & -0.4144 & $-0.6810^{* *}$ & -0.4700 & -0.0211 \\
\hline TDS (mg/L) & -0.3528 & -0.3216 & 0.2980 & -0.0739 & $-0.6570^{*}$ & -0.4187 \\
\hline $\mathrm{pH}$ & 0.5288 & -0.1543 & -0.1446 & -0.2174 & $0.7457^{* *}$ & 0.0242 \\
\hline Electrical conductivity $(\mu \mathrm{S} / \mathrm{cm})$ & -0.1503 & -0.1138 & -0.1056 & 0.0408 & -0.3848 & -0.0356 \\
\hline Total alkalinity & 0.1440 & -0.1706 & -0.2277 & -0.5160 & 0.3882 & 0.3406 \\
\hline $\mathrm{PO}_{4}^{3-}(\mathrm{mg} / \mathrm{L})$ & 0.0909 & -0.0139 & 0.2387 & 0.2556 & -0.0894 & -0.1299 \\
\hline $\mathrm{NO}_{3}^{-}(\mathrm{mg} / \mathrm{L})$ & 0.2873 & -0.0028 & 0.3064 & 0.2801 & -0.0918 & -0.1353 \\
\hline Dissolved oxygen $(\mathrm{mg} / \mathrm{L})$ & $0.5436^{*}$ & -0.0024 & $0.8219^{* * *}$ & 0.3985 & 0.2962 & -0.4751 \\
\hline
\end{tabular}

$n=12 ; r=0.5324, P<0.05 ; r=0.6614, P<0.01 ; r=0.7800, P<0.001$.

${ }^{*}$ Significant; ${ }^{* *}$ highly significant; ${ }^{* * *}$ very highly significant.

trend in these variables could have affected the amount of incident solar radiation required to stimulate phytoplankton growth at the base of the trophic levels in the two systems. In addition, the upper reaches were more of running waters than the reservoir's inlet stations, and these running waters have been identified as an inhospitable environment for the development of plankton, particularly microcrustaceans [36, 37]. The transition of the streams from lotic to lentic status at the mouth of the reservoir could have therefore enhanced the occurrence and population growth of zooplankton therein.

In conclusion, Aiba Reservoir's headwater streams could be considered threatened and negatively impacted, as indicated by their hydrology, physicochemical water quality, and zooplankton community structure. Onikan stream in particular could be highly susceptible to pollution stress due to its very low discharge, and this could negatively affect the reservoir's health downstream. The polluted and unstable habitat nature of these streams could negatively affect the physicochemical and biotic nature of the downstream reservoir. The absence of Cladocera in this study may have justified its rarity in the previous zooplankton study of the reservoir, and this could negatively affect the food preference and nutrition of zooplanktivorous fishes therein.

\section{Conflict of Interests}

The authors declare that there is no conflict of interests regarding the publication of this paper.

\section{References}

[1] J. F. Luhr, Smithsonian Earth: The Definitive Visual Guide, Dorling Kindersley, Great Britain, UK, Compact edition, 2007.

[2] UNEP GEMS/Water Programme, Water Quality for Ecosystem and Human Health, United Nations Environment Programme Global Environment Monitoring Systems (GEMS)/Water Programme, 2006.

[3] C. H. Fernando, A Guide to Tropical Freshwater Zooplankton; Identification, Ecology and Impact on Fisheries, Backhuys Publishers, Leiden, The Netherlands, 2002.

[4] T. M. Zaret, "Predators, invisible prey and the nature of polymorphism in the cladocera (Class Crustacea)," Limnology Oceanography, vol. 17, no. 2, pp. 171-184, 1972.

[5] S. I. Dodson, "Zooplankton competition and predation: an experimental test of the size efficiency hypothesis," Ecology, vol. 55, no. 3, pp. 605-613, 1974.

[6] H. A. Ayodele and I. F. Adeniyi, "The zooplankton fauna of six impoundments on River Osun, Southwest, Nigeria," The Zoologist, vol. 1, no. 4, pp. 49-67, 2006.

[7] Z. Brandl, "Methodology and general ecology," in A Guide to Tropical Freshwater Zooplankton: Identification, Ecology and Impact on Fisheries, C. H. Fernando, Ed., pp. 1-21, Backhuys Publishers, Leiden, The Netherlands, 2002.

[8] L. A. Kutikova, "Rotifera," in A Guide to Tropical Freshwater Zooplankton; Identification, Ecology and Impact on Fisheries, C. H. Fernando, Ed., pp. 23-68, Backhuys Publishers, Leiden, The Netherlands, 2002. 
[9] G. Fussmann, “The importance of crustacean zooplankton in structuring rotifer and phytoplankton communities: an enclosure study," Journal of Plankton Research, vol. 18, no. 10, pp. 18971915, 1996.

[10] C. E. Williamson, "Invertebrate predation on planktonic rotifers," Hydrobiologia, vol. 104, no. 1, pp. 385-396, 1983.

[11] C. E. Williamson and N. M. Butler, "Predation on rotifers by the suspension-feeding calanoid copepod Diaptomus pallidus.," Limnology \& Oceanography, vol. 31, no. 2, pp. 393-402, 1986.

[12] P. C. Schulze and C. L. Folt, "Food resources, survivorship, and reproduction of the omnivorous calanoid copepod Epischura lacustris," Ecology, vol. 71, no. 6, pp. 2224-2240, 1990.

[13] V. R. Alekseev, "Copepoda," in A Guide to Tropical Freshwater Zooplankton: Identification, Ecology and Impact on Fisheries, C. H. Fernando, Ed., pp. 123-187, Backhuys Publishers, Leiden, The Netherlands, 2002.

[14] M. T. Furse, "The application of RIVPACS procedures in headwater streams-an extensive and important natural resource," in Assessing the Biological Quality of Freshwaters. RIVPACS and other Techniques, J. F. Wright, D. W. Sutcliffe, and M. T. Furse, Eds., pp. 79-91, Freshwater Biological Association, Windermere, UK, 1997.

[15] O. E. Atobatele and O. A. Ugwumba, "Seasonal variation in the physicochemistry of a small tropical reservoir (Aiba Reservoir, Iwo, Osun, Nigeria)," African Journal of Biotechnology, vol. 7, no. 12, pp. 1962-1971, 2008.

[16] O. E. Atobatele and O. A. Ugwumba, "Distribution, abundance and diversity of macrozoobenthos in Aiba Reservoir, Iwo, Nigeria," African Journal of Aquatic Science, vol. 35, no. 3, pp. 291-297, 2010.

[17] O. E. Atobatele and G. O. Olutona, "Spatio-seasonal physicochemistry of Aiba stream, Iwo, Nigeria," African Journal of Biotechnology, vol. 12, no. 14, pp. 1630-1635, 2013.

[18] E. O. Akindele, "Downstream assessment of the zooplankton fauna and hydrology of Aiba stream, Iwo, Nigeria," in Proceedings of the Nigerian Tropical Biology Association Conference, pp. 47-53, 2013.

[19] E. O. Akindele and A. A. Liadi, "Diversity and response of benthic macroinvertebrates to natural and induced environmental stresses in Aiba stream, Iwo, Southwest Nigeria," West African Journal of Pure and Applied Ecology, vol. 22, pp. 101-111, 2014.

[20] E. O. Akindele and I. F. Adeniyi, "A study of the physico chemical water quality, hydrology and zooplankton fauna in Opa Reservoir catchment area, Ile-Ife, Nigeria," African Journal of Environmental Science and Technology, vol. 7, no. 5, pp. 192203, 2013.

[21] E. O. Akindele, "Relationships between the physico-chemical water parameters and zooplankton fauna of Tiga Lake, Kano, Nigeria," Bayero Journal of Pure and Applied Sciences, vol. 6, no. 1, pp. 95-100, 2013.

[22] E. O. Akindele and I. F. Adeniyi, "Zooplankton composition and community structure in Lake Tiga, Kano, Nigeria," African Journal of Aquatic Science, vol. 38, no. 3, pp. 279-286, 2013.

[23] J. O. Akintola, Rainfall Distribution in Nigeria, Impact Publishers, Ibadan, Nigeria, 1986.

[24] C. M. A. Ademoroti, Standard Methods for Water and Waste Effluents Analysis, Foludex Press, Ibadan, Nigeria, 1996.

[25] APHA, Standard Methods for the Examination of Water and Waste, American Public Health Association, Washington, DC, USA, 20th edition, 1998.
[26] A. B. M. Egborge, Water Pollution in Nigeria: Biodiversity and Chemistry of Warri River, vol. 1, Nigeria Ben Miller Books, Warri, Nigeria, 1994.

[27] J. L. Chapman and M. J. Reiss, Ecology: Principles and Applications, Cambridge University Press, Cambridge, UK, 1992.

[28] D. Chapman and V. Kimstach, "Selection of water quality variables," in Water Quality Assessments, D. Chapman, Ed., pp. 65122, Chapman and Hall, London, UK, 1996.

[29] A. A. Ayoade, S. O. Fagade, and A. A. Adebisi, "Dynamics of limnological features of two man-made lakes in relation to fish production," African Journal of Biotechnology, vol. 5, no. 10, pp. 1013-1021, 2006.

[30] E. O. Akindele, I. F. Adeniyi, and I. Indabawa, "Spatio-temporal assessment and water quality characteristics of Lake Tiga, Kano, Nigeria," Research Journal of Environmental and Earth Sciences, vol. 5, no. 2, pp. 67-77, 2013.

[31] J. R. Voshell, A Guide to Common Freshwater Invertebrates of North America, The McDonald and Woodward Publishing Company, Granville, Ohio, USA, 2002.

[32] M. L. Moore, NALMS Management Guide for Lakes and Reservoirs, North American Lake Management Society, 1989, http:// www.nalms.org/.

[33] J. P. Michaud, A Citizen's Guide to Understanding and Monitoring Lakes and Streams, vol. 360, Washington State Dept of Ecology, Publications Office, Olympia, Wash, USA, 1991.

[34] E. D. Ongley, Control of Water Pollution from Agriculture: FAO Irrigation and Drainage, Paper 55, Food and Agriculture Organization of the United Nations, Rome, Italy, 1996.

[35] N. Boatman, C. Stoate, R. Gooch et al., The Environmental Impact of Arable Crop Production in the European Union: Practical Options for Improvement, Environmental Commission Directorate-General, Environment, Nuclear Safety and Civil Protection, Allerton Research and Educational Trust, Leicester, UK, Eurinco, Brussels, Belgium, ERENA, Lisbon, Portugal Centre of Environmental Science, Lieden University, Lieden, The Netherlands, 1999, http://ec.europa.eu/environment/agriculture/pdf/arable.pdf.

[36] P. N. Owens, R. J. Batalla, A. J. Collins et al., "Fine-grained sediment in river systems: environmental significance and management issues," River Research and Applications, vol. 21, no. 7, pp. 693-717, 2005.

[37] C. E. Shannon, "A mathematical theory of communication," The Bell System Technical Journal, vol. 27, pp. 379-423, 1948.

[38] D. R. Lenat, L. A. Smock, and D. L. Penrose, "Use of benthic macroinvertebrates as indicators of environmental quality," in Biological Monitoring for Environmental Effects, L. W. Douglass, Ed., Lexington Books, Toronto, Canada, 1980. 

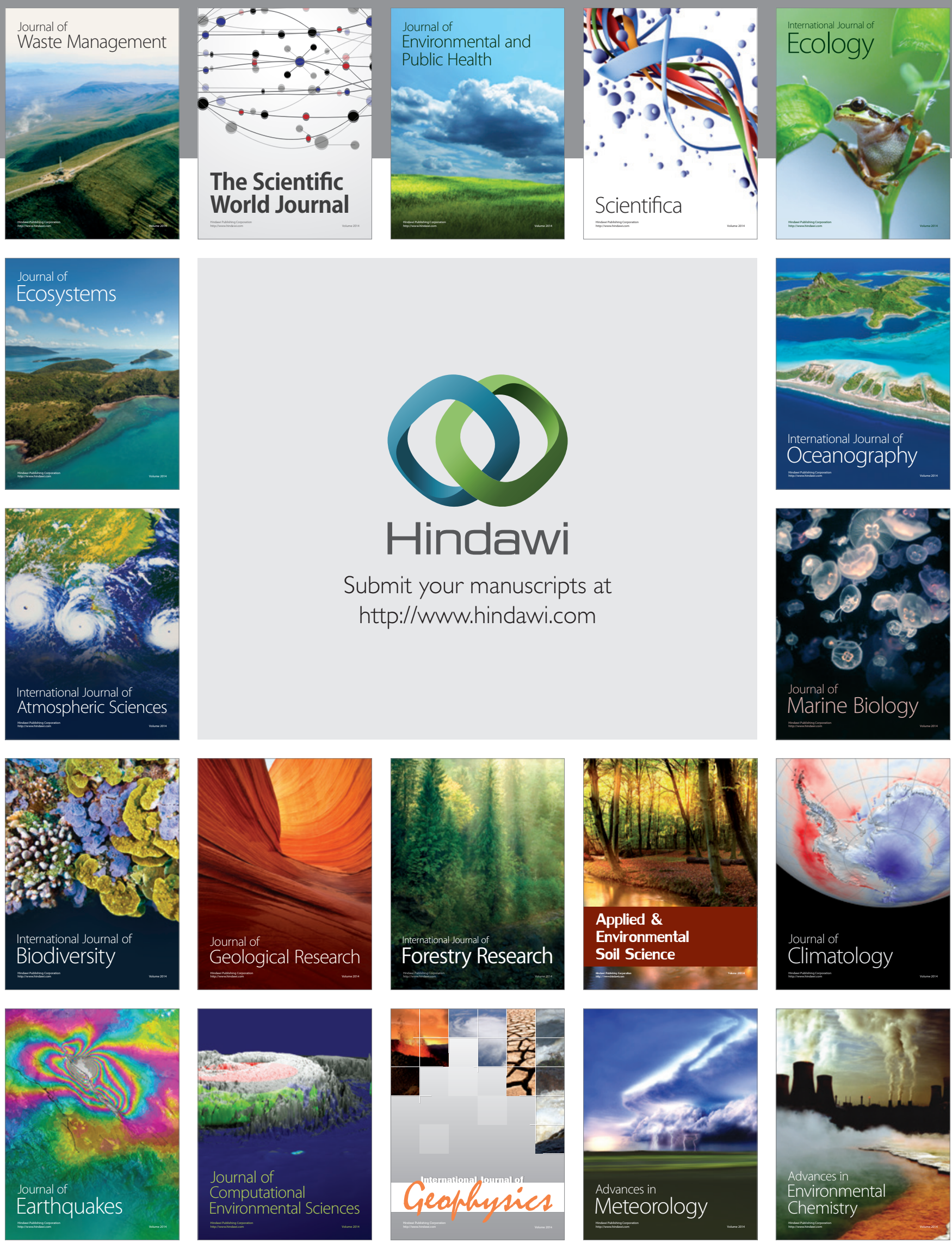